\title{
CURRENT STATE AND POSSIBILITIES OF DEVELOPMENT OF LONG-TERM BANK LENDING TO NON-FINANCIAL INSTITUTIONS IN RUSSIA
}

\author{
Maxim M. Sytnik \\ Department of Finance and Monetary \\ Tyumen State University \\ Tyumen, Russia \\ sytnikmax@gmail.com
}

\begin{abstract}
The article analyzes the current state and the dynamic trends of long-term bank lending in Russia, the main indicators characterizing the development of long-term lending to non-financial corporations, commercial banks and its impact on the real economy. As a result of the study of the dependence of rates on long-term bank loans from short-term rates of banking market, it was found out that during the increase of the key rate, banks primarily increase rates on the short-term programs. Thus, as the total cost of lending grows, the cost of long-term lending may be lower than that of the short-term lending. It is determined that the relationship between the growth rate of short-term rates and the spread between short-term and longterm rates is negative. It was also concluded that, in spite of accelerating pace of the development of long-term lending in Russia, it does not provide the necessary growth rate of the investments in fixed assets of organizations, which is partly due to an increase in the share of loans to non-residents of the country.
\end{abstract}

Keywords: banking system of the Russian Federation, longterm lending or crediting, GDP, investments, inflation expectations, fixed assets.

\section{INTRODUCTION}

Long-term bank lending, as one of the most important financial instruments of the real sector of the economy, must satisfy the need of non-financial organizations for investment, ensuring economic growth in the country. Long-term loans are a stable income for banks: however, due to the instability of the financial market and interest rates, the long-term lending is associated with increased risks for banks.

The purpose of the article is to investigate the dynamics of the main indicators of bank lending and to identify factors that have a deterrent effect on the supply of long-term loans from credit institutions.

\section{THEORY}

Within the framework of this article, long-term bank lending refers to the lending by commercial banks of nonfinancial organizations, including individual entrepreneurs, for a period of more than three years. In the Russian legislation, there are no clear criteria for classifying loans by maturity, so the grouping of bank loans in terms of urgency depends on the purpose of the study.
According to the guidelines of the Bank of Russia 139-I, long-term assets are the assets with the demand period of more than one year ${ }^{1}$. In the bank chart of accounts, the issued loans are shown on the accounts of the second order in terms of timing; the groups of loans for a period of one year up to three years and over three years are marked out ${ }^{2}$. Since all loans for a period of more than three years are shown in the same accounts of the second order, there is no more detailed statistics on the terms of lending in the Russian Federation. It means that it is not possible to determine the amount of loans extended for more than five years, more than ten years, and so on [1].

Due to the fact that the dynamics of long-term loans as one of the most important sources of investment is analyzed, the loans for a period of more than three years were chosen as a subject of research since the loans with such landing period are granted for the investment purposes. The loans for a period of one to three years, in turn, are mostly used for replenishment of working capital; therefore, they are not considered as long-term. It should be added that in other countries, particularly in Europe, more detailed analysis of loans by maturity is conducted. Loans are given for a period of one year, from one year to three years, from three to five years, from five to ten years and for more than ten years, which implies that the loans granted for less than three years are not considered long-term.

\section{DATA AND METHODS}

The information base of the research is provided by the data of the Federal State Statistics Service of Russia, the Central Bank of the Russian Federation, reporting data of commercial banks, statistical materials published in the mass media and Internet resources. The methodological basis of the research consists of scientific and special research methods: system and comparative analysis, methods of grouping, generalizing and comparative information, indicators of mathematical statistics.

\footnotetext{
${ }^{1}$ Instruction of the Bank of Russia of 03.12.2012 \# 139-I "On the mandatory standards of banks" (ed. of 15.11.2016)

${ }^{2}$ The position of the Bank of Russia of 27.02.2017 \# 579-P "On the chart of accounts for credit institutions and the manner of its application" (ed. of 27.02.2017)
} 


\section{RESULTS}

The volume of long-term loans provided by commercial banks has steadily increased over the last ten years against the backdrop of a general increase in the assets of the banking system of the country; as of 01.01.2017, the total volume of such loans amounted to 17.163 billion rubles (Fig. 1).



Fig. 1. Dynamics of long-term loans and their share in GDP, \%3

The exception was in 2016, following which the balances of long-term loans in commercial banks fell by $4.3 \%$. The largest increase was recorded in 2007-2008; at that time, balances on long-term loans of Russian banks increased by 55$95 \%$ per year.

According to the growth of an absolute value of credits, their relation to GDP of the country had increased; from 2007 to 2015. This indicator had increased from 3.5 up to $21.6 \%$, which indicates a qualitative increase of long-term lending, rather than simply increasing its volume in current prices at the level of the GDP growth rate.

Over the period under review, the growth of long-term loans not only outstripped the growth rates of GDP, but significantly exceeded the dynamics of the corporate loan portfolio as evidenced by structural changes in the composition of the bank loan portfolio by maturity (Fig. 2)

\footnotetext{
${ }^{3}$ Calculated from the official website of the Federal State Statistics Service: [Electronic resource] URL: http: //www.gks.ru/ and the Official site of the Bank of Russia: [Electronic resource] - URL: www.cbr.ru
}

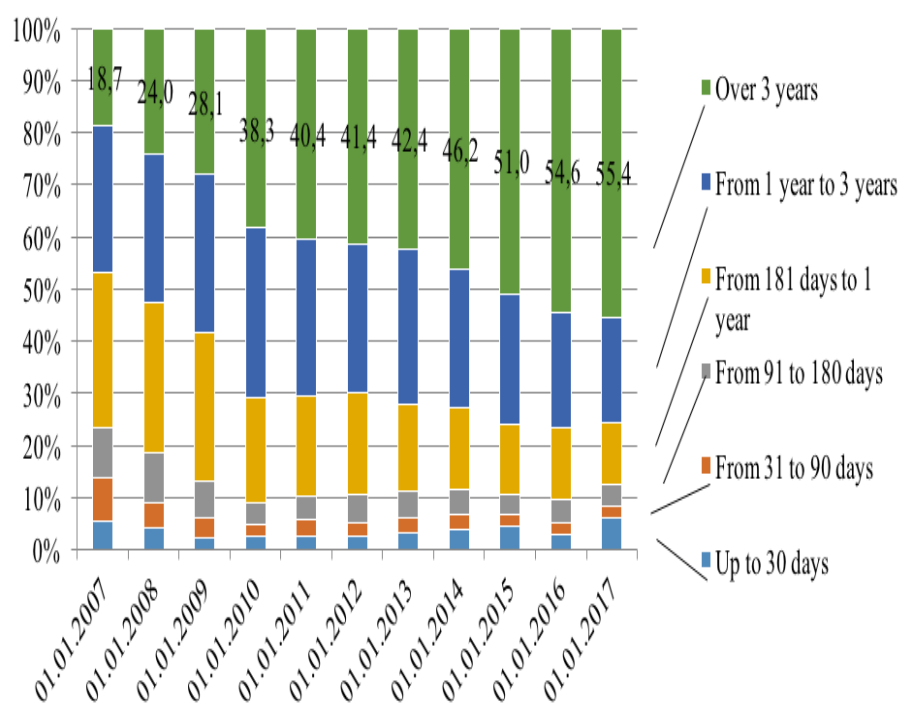

Fig. 2. Structural dynamics of loans to non-financial organizations by terms, $\% 4$

Fig. 2 shows that for the period of 10 years, the share of long-term loans granted for a period of more than three years has increased from 18.7 to $55.4 \%$ in the structure of assets of Russian banks, i.e. more than half of the debts of non-financial corporations to banks are long-term loans.

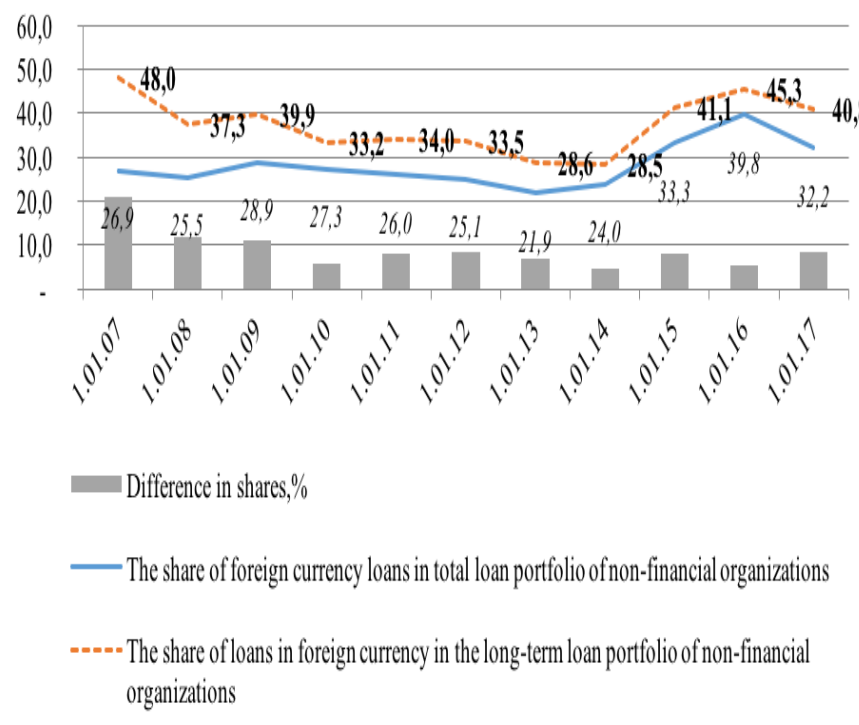

Fig. 3. Specific weight of the long-term credits in foreign currency in a portfolio of the Russian banks, \%

The indicated tendency positively characterizes the dynamics of the development of the country's banking system and indicates a better transformation of short-term into a longterm liquidity. It is worth noting that by the end of 2016, the share of long-term loans had also increased in the structure, despite the reduction in absolute terms, which indicates a

\footnotetext{
${ }^{4}$ Calculated according to the official site of the Bank of Russia: [Electronic resource] - URL: www.cbr.ru
} 
general decline in bank loan portfolio. However, it is not considered as a trend of long-term loan dynamics.

In case of the structure of the credit portfolio of the Russian banking system in the section of currencies, another important trend in the development of long-term lending in the Russian Federation can be identified. In the total amount of debt of non-financial organizations for long-term loans, more than $40 \%$ are loans granted in foreign currency (Fig. 3).

\section{8}

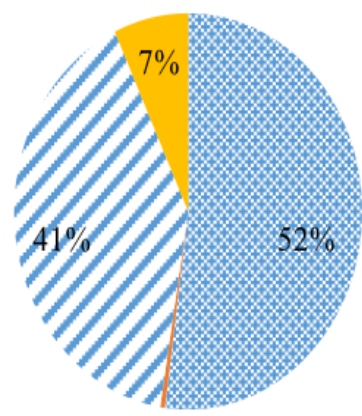

$0 \%$

\section{6}

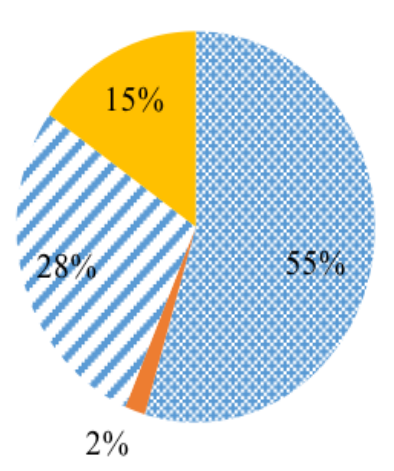

For residents in rubles

For non-residents in rubles

$\triangle$ For residents in foreign currency

For non-residents in rubles

Fig. 4. The structure of the long-term loan portfolio of Russian banks basing on the residency, $\% 5$

Cumulative specific weight of the credits given to legal entities in foreign currency in the total value of the loan portfolio fluctuates within the last 10 years around $23-30 \%$. At the same time, in a portfolio of long-term loans, the share of the credits in a foreign currency throughout the entire period of analysis is higher ranging from 28 to $48 \%$. On Janury 1, 2017 , the share of foreign currency loans as part of long-term loans amounted to $40.8 \%$. This means that despite the need for the country's economy in long-term resources, almost half of the loans are issued in the currency of other countries, mainly dollars and euros. From the point of view of hedging currency risks, it is advisable to make currency borrowings exclusively

${ }^{5}$ Calculated according to the official site of the Bank of Russia: [Electronic resource] - URL: www.cbr.ru for those companies that work with foreign exchange earnings (exporters). However, the question arises whether these longterm foreign currency loans are actually provided to the resident exporters or there is an outflow of long-term liquidity from the country. Since a significant portion of long-term loans issued by the Russian banks fall to loans in foreign currency, it is advisable to consider the distribution of these loans basing on the residency (Fig. 4).According to the obtained calculations, as of 01 January $2017,28 \%$ of all loans are the loans to residents in foreign currency; the share of loans to non-residents in foreign currency is $15 \%$ of the loan portfolio, i.e. a great part of the currency loans is granted to residents of the country. Nevertheless, $17 \%$ of all issued longterm loans in total would be the share of nonresidents; in 2008, this share comprised $7 \%$.

Thus, despite the increase in long-term lending to business by Russian banks, part of the increase is accounted for nonresidents, which reduces the financial effectiveness of lending for Russian economy. From the point of view of the authors, it was the increase in lending to non-residents that affected the change in the relationship between the dynamics of investment in the fixed capital of organizations of the Russian Federation and the growth rate of long-term lending (Fig. 5).

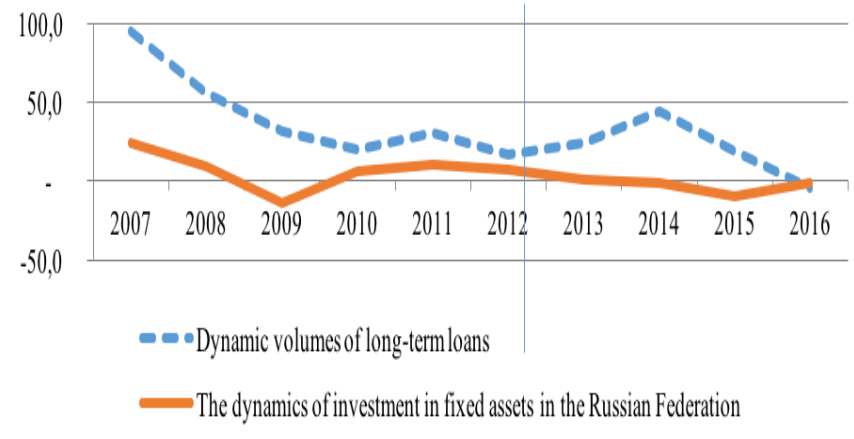

Fig. 5. Compliance of growth rates of investments into fixed capital and long-term crediting, \%6

From Fig. 5 it can be seen that until 2013, the movement was unidirectional and the change of volumes of long-term crediting was followed by the corresponding dynamics of investments, which indicated the targeted orientation of longterm loans for investment in fixed assets of Russian companies. Since 2013, the direct link between the indicators has disrupted, the dependence has become inverse, i.e. the growth of long-term lending ceased to influence the dynamics of investment in fixed assets. As a result, the rate of investment growth has decreased and for the last three years, the negative dynamics has been observed.

Thus, it is possible to conclude that positive dynamics of growth rates of long-term bank lending and essential increase in such credits in assets of commercial banks did not exert the necessary impact on development of the real sector and growth of investments into fixed assets of Russian

${ }^{6}$ Calculated from the official website of the Federal State Statistics Service: [Electronic resource] URL: http: //www.gks.ru/ and the Official site of the Bank of Russia: [Electronic resource] - URL: www.cbr.ru 
organizations in connection with the increase in the share of long-term loans issued outside the Russian Federation.

Another important aspect characterizing the development of long-term lending in the country is the dynamics of interest rates on such loans, as well as their connection with the rates on short-term loans (Fig. 6).

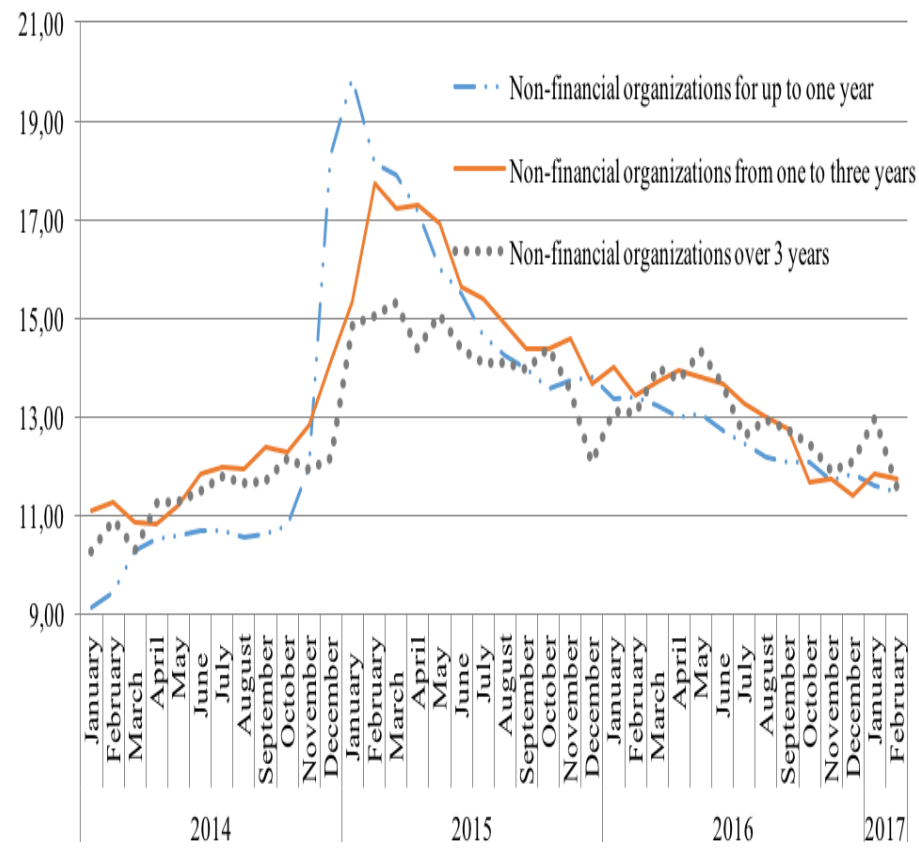

Fig. 6. Dynamics of interest rates on loans to non-financial organizations, $\% 7$

Fig. 6 shows the dynamics of loan interest rates to nonfinancial organizations in 2014-2017 for the lending period. The relation between short-term and long-term rates at different time intervals is clearly observed. In 2016, the average cost of long-term loans was higher than the cost of loans granted for a shorter period. In 2015, the trend was reversed, i.e. there was a general increase in interest rates due to the increase of the key rate of the Bank of Russia. The rate on long-term loans increased at a slower pace; therefore, the cost of long-term financing was lower than the cost of shortterm loans.

To determine the relation between rates, the interest spread was calculated (the difference in the rate of long-term and short-term loans (up to a year) for the relevant month). Fig. 7 shows the spread line and the dynamics of the interest rate on short-term loans up to a year.

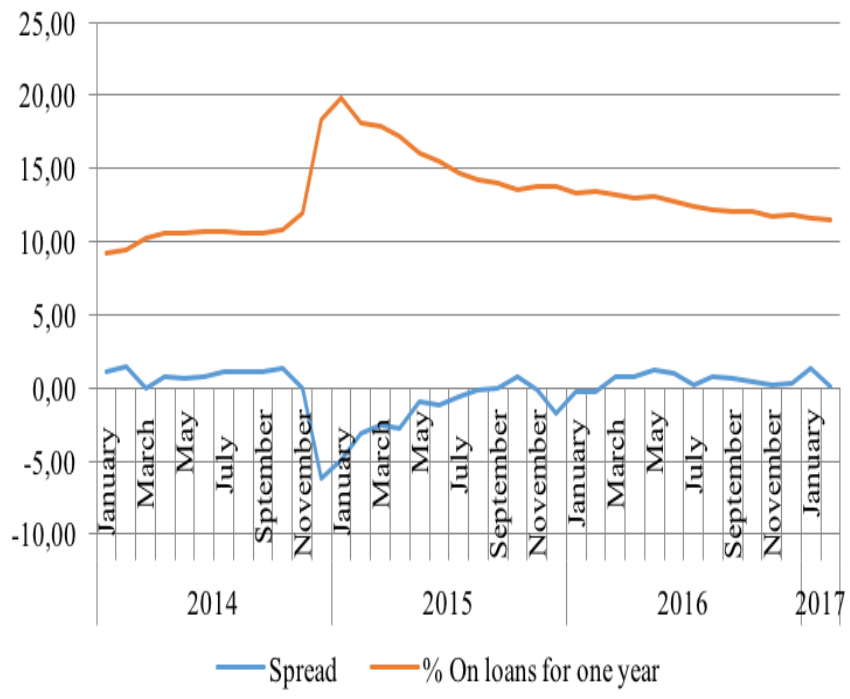

Fig. 7. Dynamics of interest spreads and interest rates on short-term loans up to one year, $\% 8$

Fig. 7 clearly shows the inverse relationship between the displayed variables. It is obvious that there is a correlation between the dynamics of short-term rates and the interest spread. To determine the relation on the basis of the data used for the diagram, the correlation of the spread and the magnitude of interest rates on loans up to one year for the period from January 2014 to February 2017 were calculated by means of MS Excel. As a result, the value of 0.87 was obtained. It can be concluded that the relation is very close and inverse. Thus, if the interest rates on short-term loans tend to increase, the spread between the rates strives to negative value and the cost of short-term credit becomes higher than the cost of long-term credit. On the contrary, when the shortterm rates are reduced, there is an increase in spread towards a positive value, i.e. the cost of rates of long-term loans becomes higher than the cost of rates of short-term loans.

This tendency makes it possible to conclude that in the conditions of growth of the key rate of the Bank of Russia, banks would initially increase the interest rates on short-term programs. At the same time, the cost of long-term lending does not dramatically increase. In the conditions of stabilization observed in 2016, the rates of long-term loans began to increase relatively to short-term rates. As a result, in September 2016, due to lower key rates and the corresponding reduction of interest rates on the credit market, the cost of long-term loans consistently exceeds the rates on other loans. Gabriele Tondl in a similar study of the dynamics of rates in Europe comes to a similar conclusion regarding the dependence of spread, the size of short-term rates and the direction of their change [2]. In the normal state of economy, the spread between the rates should be positive, i.e. long-term rates should exceed short-term rates; however, the larger the spread, the greater the risk of fee for long-term lending, which is a consequence of negative expectations of credit

${ }^{8}$ Calculated according to the official site of the Bank of Russia: [Electronic resource] - URL: www.cbr.ru

\footnotetext{
${ }^{7}$ Calculated according to the official site of the Bank of Russia: [Electronic resource] - URL: www.cbr.ru
} 
institutions. In other words, the spread between the rates characterizes the expectations of economic entities, mainly banks, regarding future macroeconomic indicators, such as inflation and the corresponding key rate of the Bank of Russia:

- if a significant reduction in the inflation and the key rate of the regulator is expected, credit institutions reduce the cost of long-term lending relatively to a short-term lending;

- when predicting the stability of key indicators, rates are almost equalized and there is a slight excess of the cost of long-term funding taking into account the insignificant risk payment;

- while waiting for the growth rates in the long term and the instability of the economy, rates on long-term loans are significantly higher than the interest rates on short-term loans.

Investigations on the relation between inflationary expectations and the development of long-term lending are devoted to the work of I.N. Gurov, in which the author also determines the relation among rates, inflation expectations and the growth of long-term lending in the Russian banking sector [1]. In its turn, the development of long-term lending should positively affect the profitability of the banking sector and should contribute to the economic growth [3]. Since now the spread between the rates is minimal (Fig. 7), it allows us talking about stabilizing the Russian economy and reducing inflation expectations of the banks, which, all in all, should lead to the growth of volume of long-term crediting and its demand from the real sector.

\section{CONCLUSION}

As a result of the study it, was determined that the investment loans with the original maturity of more than three years should be considered as long-term bank loans. The following conclusions were made about the trends of development of long-term lending in the period of 2007-2016:

- significant increase in the volume of debt on long-term loans in absolute terms and in the structure of the loan portfolio of the Russian banking sector;

- increase in proportion of long-term bank loans to nonfinancial corporations in GDP;

- increase in proportion of foreign currency long-term credits and loans granted to non-residents;

- since 2013, the correlation between the growth rate of investment in fixed assets and growth in long-term lending has transformed from positive to negative;

- in 2016, the stabilization of spread between long-term and short-term interest rates and their systematic reduction has occurred.

The positive dynamics of growth of long-term bank lending and a significant increase in long-term loans in commercial bank assets has not had a corresponding impact on the development of the real sector and the growth of investment in fixed assets of Russian companies. Partly it was because of the increase in the share of long-term loans issued outside the Russian Federation. The dynamics of interest rates on long-term loans and the indicated dependence of the development of long-term lending on inflation expectations allow us to expect positive growth rates of long-term bank loans to non-financial institutions, provided that certain conditions are met, mainly it would be the creditworthiness of the borrowers and their investment activity.

\section{References}

[1] O.S. Miroshnichenko, M.M. Sytnik, "Bank long-term lending to corporate borrowers and economic growth in Russia", "ECONOMICS. BUSINESS. BANKS", No 2 (19), pp. 20-38, 2017

[2] G. Tondl, Interest rates, corporate lending and growth in the Euro Area, 2016, Department of Economics Working, Paper No. 227.

[3] I.N. Gurov, Capital expenditures for the financing of innovative projects: an assessment of the premium for the risk of inflation, Creative economics, No. 6 (90), pp. 34-48, June 2014

[4] N.S. Voronova, O.S. Miroshnichenko, A.N. Tarasova, Determinants of the development of the Russian banking sector as factors of economic growth, Economic and social changes: facts, trends, forecast, No. 4, pp. 165-183, 2016. Doi: 10.15838 / esc / 2016.4.46.9 